\title{
Rødding bydistrikts historie
}

\author{
Ved Jobs. Rosendabl.
}

\section{Indledning}

Johannes Rosendahl var ikke sønderjyde, men Sønderjylland blev den del af Danmark, han kom til at føle sig stærkest knyttet til, Sønderjylland nord og syd for grensen.

En del år boede og virkede han i Sonderjylland. Som nybagt cand. polit. kom han sidst i $30^{\prime}$ rne til Rødding Højskole som lærer. Han virkede her til kort efter krigen. Siden var han en tid handelskonsulent i Sydslesvig. Han og hans kone, Aase, datter af forstander Hans Lund, Rødding, boede da $\mathrm{i}$ et lille hus ved Kollund, og hver dag tog Rosendahl over grænsen, ikke blot for at være rådgiver $i$ økonomiske anliggender, men for at tage del i hele det danske kulturliv. Han vandt sig da mange venner i Sydslesvig.

Siden var han i nogle år lærer på Idrætshøjskolen i Sønderborg. Herfra kom han som forstander til gartner- og frugtavlerhøjskolen "Søhus" ved Odense. I 1967 blev han udnæevnt til forstander for Andelsskolen ved Middelfart. Han blev syg kort efter sin tiltræeden og døde i efteråret 1969.

Rosendahl burde måske have fået sit varige virke i Sønderjylland, hvis natur og mennesker han satte så højt.

Under den anden verdenskrig var han aktiv i modstandsbevxgelsen. Han deltog $i$ adskillige sabotageaktioner og rykkede ind $i$ ledelsen af Region III.

Nolende gik han ind i modstandskampen, men da han havde truffet sit valg, satte han hensynsløst alle sine krxfter ind på kampen mod den tyske militærmagt.

I sine sidste leveår arbejdede Rosendahl intenst med en bog, der skulle bære titlen "Dagværk - Natarbejde«. Første del skulle fortxalle om "langtidskampen " i Sønderjylland fra 1864 til 1918 og om de metoder, som denne form for kamp krævede. Men i første 
Johannes Rosendahl, 24. 10. 1912-29. 9. 1969.

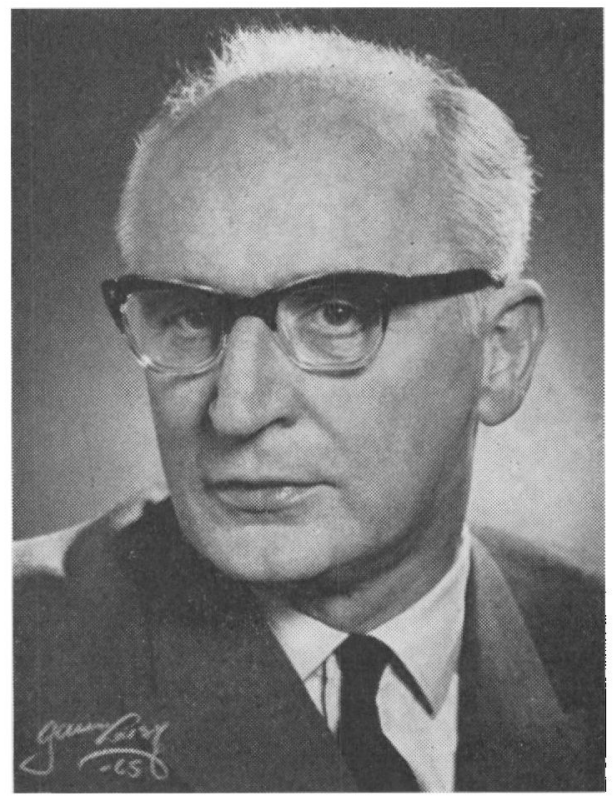

række ville Rosendahl fortælle om de personligheder, der stod i forreste linje i denne kamp. Dem havde han fået stor respekt for. Anden del, natarbejdet, skulle handle om modstandskampen.

Desværre blev den store bog ikke skrevet færdig. Nedenstående afhandling er et kapitel fra anden del. Der foreligger flere udkast til denne skildring. Den, som her bringes, er nedskrevet få år efter begivenhederne.

Et afsnit af første del af bogen er offentliggjort i "Dansk Udsyn ", nr. 5, årgang 1970. Det beretter om Ludvig Schrøder og Cornelius Appel. Det er en kritisk fremstilling af Ludvig Schrøder. Erfaringer i modstandskampen har for Rosendahl kastet nyt lys over fortidens skikkelser.

Richard Andersen.

Sidst $\mathbf{i}$ juli måned 1944 kom kaptajn Høiland Christensen under dæknavnet Thygesen ${ }^{1}$ første gang til Redding for at oprette modstandsgrupper, og han opsøgte $»$ Ringen «s tillidsmand $\mathrm{i}$ byen.

Denne havde i oktober 1943 berejst Jylland for i forbindelse med Bispebjerg Hospital at organisere transporten til Sverige af de endnu 
tilbageværende jøder, og ved denne lejlighed var det, at han var blevet opmærksom på nødvendigheden af en mere aktiv modstand mod besættelsesmagten. Han indvilligede derfor straks $i$ at forsøge på at oprette grupper i Rødding og omegn, dels sabotagegrupper, dels almindelige militærgrupper.

Ingen kunne være $\mathrm{i}$ tvivl om, at Højland Christensen var officer. Holdning og stemmeføring røbede det. Hans blik var fast og roligt, læberne smalle, munden ofte lidt sammenbidt. Let kom man til at tænke på, at han kunne stamme ned fra en eller anden dansk adelsslægt - en af dem, der er stolte af at eje adskillige, kendte feltherrer. Der var forøvrigt en ejendommelighed ved hans ansigt. Der var en modsætning mellem øjnenes og mundens myndige afgjorthed og næsens åbenbart utøjlelige tendens til at gå i vejret. Næsen hørte hjemme i slægter, hvis skoledrenge har voldt deres lærere adskillige kvaler; men denne næse havde sin mission: den kastede et forsonende skær over ansigtets mere barske egne. På intet tidspunkt udgjorde den et dominerende tr $x \mathrm{k}$ - den blev holdt i skak af sine omgivelser: en ligevægt, der måske var tilstræbt, var til enhver tid til stede. Kaptajn Højland Christensens væsen var iøvrigt tosidet. Den ene side, der kom frem, når han arbejdede, kan alene karakteriseres ved ordet: myndig, - den anden, der kom frem - eller kunne komme frem - i selskaber eller ved forhandlinger med ligestillede eller overordnede, kan fuldt ud dxkkes af fremmedordet: chevaleresk.

Således var den mand, der på "Ringen«s foranledning begyndte arbejdet i Rødding bydistrikt. - Foreløbig blev der dannet 2 grupper i Rødding, 2 i Langetved, én i Jels og én i Askov. Askov-gruppen, som var dannet gennem læge Karl Teilmann," kom senere ind under Vejen; forsøget på at danne en gruppe i Gram strandede fuldstændigt, men dette skete kun, fordi der dér allerede i forvejen var dannet et par grupper. Vort forsøg i Gram førte med sig, at vi fik en ikke unyttig kontakt med disse dygtige grupper gennem musiker Lausen.

August måned gik, uden at vi hørte mere fra Thygesen. Vi havde anmeldt vore grupper til en dxkadresse i Vejle, og det var lovet os, at der skulle blive sendt en instruktør. Men vi hørte intet. Meget utålmodige søgte vi forbindelse med regionsledelsen om ad musikeren, og denne etablerede også en kontakt mellem "Ringen «s repræsentant og »Anders « $\mathrm{i}$ forsamlingshuset $\mathrm{i}$ Vedsted. Vi fik et par koder med 
til Rødding, blev instrueret $i$ brugen af våben og sprængstof, fik løfte om en instruktør og medbragte den lille 4-sprogede vejledning i sabotage. Imidlertid førte forbindelsen med $»$ Anders $«$ ikke til noget yderligere, idet han kort efter blev skudt den 27 . september.

"Anders \& gjorde indtryk af at være meget uforsigtig. På den anden side havde man ikke været længe sammen med ham, før man forstod, at han var en særdeles nidkær frihedskæmper. Når man forlod forsamlingshuset, takserede man ham til at være underofficer og til at leve $i$ spæending som en fisk $i$ vand; - men man bebrejdede ham afgjort, at han fortalte mere, end nødvendigt var. Med beklagelse, men ikke med forbavselse, hørte man, hvad der var sket i V. Vedsted dagen efter kongens fødselsdag 1944.

Ved en anden lejlighed søgte musiker Lausen at etablere et møde mellem Rødding og Poulsen junr. ${ }^{5}$ Sidstnævnte udeblev imidlertid og dette var måske meget heldigt.

Netop som Lausen engang $i$ oktober med møje havde skaffet forbindelse mellem Rødding og "Frode ${ }^{\circ}$ i Haderslev, lod Thygesen pludselig høre fra sig. Nu skulle der pustes liv i grupperne i det midterste af Sønderjylland. Thygesen, ' der nu hed Peter Jensen, stillede instruktioner, våben og sprængstof $i$ udsigt og tilbød endvidere samtidig Røddings mand at blive "Ringen «s representant i regionsledelsen. Foreløbig kunne han dog godt fungere videre som byleder.

De første instruktioner havde vi dog på dette tidspunkt allerede modtaget, ikke på regionsledelsens, men på »Ringen «s foranledning. Den 11. september havde Søbæk ${ }^{8}$ indfundet sig i Rødding for at undervise i brug af våben; senere, engang i november, ankom $» P e r «^{\circ}$ og gav undervisning $\mathrm{i}$ brug af sprængstof. Det foregik $\mathrm{i}$ højskolens villa på Møgelmosevej.

Søbæk var en ung mand, sidst $i$ tyverne, der på det tidspunkt mest af alt lignede en ekspedient $i$ en trikotageforretning. Ikke et øjeblik mistænkte man ham for at have noget kendskab til skydevåben; et let overskæg gav ham endda et ret feminint udseende, og under samtale med ham mærkede man sig en lidt uopmærksom væremåde. Snart blev det dog klart, at han alle symptomer til trods måtte være en ung officer - specielt uddannet $i$ håndvåben - og senere endnu, da han fik overskægget af, oplevede man, at der skete en ganske betydelig forandring med ham. Ethvert spor af det feminine forsvandt - ja, ret virile træk blev de dominerende - og man syntes 
tydeligt at kunne ane, hvorledes han ville komme til at se ud som xldre soldat: han ville fole sig hjemme $i$ en officersmesse; allerede nu satte han pris på en vanvittig engelsk short-story; - måske nød han den dog som spiritus mere for virkningens skyld - i hvert fald hengav han sig ganske selvforglemmende til den efterfølgende støjende latter. Han vil engang komme til at holde mere af sin hest end af sin kone: han er helt igennem officer.

"Per« vil altid blive husket for den måde, hvorpå han introducerede sig selv: "Jeg heter Pe-er«, sagde han på klart norsk. Da ingen ventede, at en illegal mand talte et fremmed sprog, var svaret altid et uforstånde $*$ Hvadbeha'r? $*$. Han kunne derfor indtil flere gange komme ud for at gentage sit kaldesignal. - Per var oprindeligt forstkandidat. I et interview $\mathrm{i}$ "Jydske Tidende* har han fortalt om sine mærkelige oplevelser. Per var yderst ligefrem, selvfølgelig og vindende $\mathrm{i}$ sin væremåde. Man vil sige om ham, at både hans væesen og mere specielt også hans gang mindede om en jysk bondekarls; men han var dog mere smilende og charmerende, end jyden $i$ almindelighed er det.

En dag i december kom der bud, at vi skulle være klar til at modtage de første våben. De kom pr. lastbil og blev kørt til Niels Baggers gård bag højskolen. Det drejede sig om 48 karabiner, 24 MP'er og 2 MG'er med tilhørende ammunition. Først lige op mod jul fik vi pistoler.

Gårdejer Niels Bagger ${ }^{10}$ blev os til stor hjælp ved opbevaringen af våben og senere navnlig ved opbevaringen af sprængstof. Han var en stilfærdig bonde på godt 40, der var særdeles fremmed for alt, hvad der angår krig; langsomt kom han imidlertid med, og han vænnede sig lidt efter lidt til faren, drevet af en følelse af pligt. Regionsledelsen husede han senere gxstfrit et par gange ved de ugentlige møder. Niels Bagger er et eksempel på, at en noget religiøs natur med en sund tillid til forsynet giver sig faren i vold, når hans samvittighed byder ham det.

Våbnene blev fordelt til Langetved (Kresten Hanssen), ${ }^{11}$ Jels (Andreas Lunding), ${ }^{12}$ Gram (musiker Lausen) og Skodborg, hvor der var dannet en R-gruppe. Resten plus de Rødding-våben, der ikke skulle anvendes ved sabotage, blev muret ind under arkitekt Jensens ${ }^{18}$ trappe $i$ hans hus i Stendevang.

Vi fik nu besøg af Sven Hoffman (Hans), ${ }^{14}$ der blev vort forbindel- 
sesled mellem bylederen og regionsledelsen. Hans var en ret spinkel ung mand først i tyverne; han var åbenbart "noget på et kontor «. Ingen skulle mistænke ham for at have krigeriske hensigter. Hans ansigt var alt andet end robust - han gjorde nærmest et sart indtryk; en fint formet næse og en ikke for stor mund prægede ansigtet. Han havde en god hukommelse og et klogtigt initiativ, og hvad der måske navnlig gjorde ham egnet til at klare sine opgaver var en overordentlig stor portion omgængelighed; lige venligt kom han med ordrer, irettesættelser og opmuntringer.

I løbet af januar måned blev vi fortrolige med våbnene, og vi øvede os $i$ at lave bomber af forskellig slags. En del fardige bombeladninger og nogle MP'er anbragte vi i øvrigt på loftet i Føvling kirke. Låsen til tårnet var ret let at ødelægge; den blev ikke beskadiget mere, end at den fortsat kunne forblive på døren, der aldrig blev benyttet.

Hovedparten af vort sprængstof derimod stod en tid lang hos højskolelærerinde Inge-Margrethe Hanssen ${ }^{15}$ i skolens villa på Tennisvej.

- I begyndelsen af februar måned fik vi for første gang ordre til at rykke ud. Det havde været regionsledelsens hensigt at holde grupperne inde $\mathrm{i}$ landet intakte, således at de kunne stå som reserve, når krigen nærmede sig sin afslutning. Det var natten mellem den 7.-8. februar, at vi første gang forsøgte os som sabotører. Røddinggruppen - ca. 12 mand - tog til tværbanen mod nord; Langetvedgruppen derimod til østbanen ved Farris. Langetved-gruppen var under ledelse af landmand Kresten Hanssen, »Højvang«. Han vil senere blive omtalt.

Tværbanen blev angrebet mellem Holsted og Brørup, og man kørte frem til stedet $i$ to biler. Bomber og våben blev for forste gang hentet $\mathrm{i}$ Føvling kirke, og det var hensigten at lave en afsporing med en almindelig dobbeltsprængning på hver side. Langsomt krøb man langs med hegnet ved Tuesbøl.

Pludselig hører man adskillige tyske vagter gå på den anden side hækken kun få meter borte. Første gang, man skal være rede til at skyde på mennesker, virker det afgjort meget stærkt.

Denne gang blev der dog heldigvis ikke brug for MP'erne. Tyskerne trak sig bort, og vi kunne uhindret rykke ned i gennemskæringen mod banen. Temmelig nervøse gik vi ned mod banen og 
fordelte os mod øst og vest, og ret nervøse lagde vi den store afsporingsladning på skinnerne. Vi har aldrig siden opholdt os să længe på banelegemet, og vi har aldrig siden fået et så dårligt resultat. Detonatorerne gjorde vi fast i sidste øjeblik, og bomberne blev under stort besvær sat ind i siden på skinnerne og med ståltråd og træplader gjort fast. Det var særdeles omstændeligt. Så meget sørgeligere var det, at da der kort tid efter kom et langt godstog rullende, var det kun tågesignalerne, der sprang, bomberne eksploderede ikke, og heller ikke mod vest skete der nogetsomhelst. Mod øst blev der derimod en dobbelt-bombe antændt med bickford i sidste sekund, og et par skinner blev ødelagt; men allerede næste formiddag blev trafikken genoptaget.

Et trist resultat.

Bedre gik det samme nat på østbanen mellem Farris og Sommersted. Fem mand fra Langetved væltede her fire vogne af et tysk orlovstog og afsporede to andre. Mærkeligt nok blev ingen dræbt; men det var uundgåeligt, at flere kom til skade. En af vognene stod fast dybt nede i moradset langs banelinjen. - En begynderfejl var her skyld i, at ikke endnu flere vogne væltede. For at skåne lokomotivet, der havde dansk lods om bord, indskød vi altid et stykke bickford-lunte mellem tågesignalet og detonatoren. Stykket var ved denne lejlighed blevet ca. en centimeter for langt, og for mange vogne nåede derfor at smutte forbi, inden bomberne sprang. Men også af denne fejltagelse drog vi lære. Også ved Farris gav begyndernervøsiteten sig udslag, idet man på hjemvejen kom bort fra hinanden. En kom således først hjem om morgenen, efter $i$ nattens løb anden gang at have været ved det væltede tog, hvor en voldsom snakken og surren fortalte, at man natten igennem havde travlt med at finde rede på sig selv under de så pludseligt ændrede omstændigheder. Forbirangering blev først mulig den 10. om aftenen kl. 18 .

Således begyndte de grupper deres arbejde, som regionsledelsen umiddelbart efter den 5 . maj omtalte som de bedste $R^{1}$-grupper, der arbejdede i Region III.

Aftenen efter kom den berømte »Langelænder «-ordre i radioen fra England. Den var ensbetydende med, at alle $\mathrm{R}^{1}$-grupper i Sydjylland skulle $\mathrm{i}$ arbejde. "Langelænder-ordren « gjaldt $\mathrm{i}$ tre dage.

$\mathrm{Da}$ det ikke var muligt for os at komme ud allerede den første aften, måtte vi vente et døgn. Det samme gjaldt Langetved-folkene. 
Natten mellem den 9.-10. februar rykkede så tre mand ud få hundrede meter vest for det gamle angrebssted. Vi havde hørt, at linjen var blevet txt besat med vagter, da store troppekontingenter fra Norge skulle passere ned gennem Jylland; men en rekognoscering om eftermiddagen tydede ikke på særlig stærk vagt - kun for hver 200 meter gik der et par mand. Om aftenen så det imidlertid anderledes ud.

Langsomt rykkede vi ned langs et hegn, indtil vi få meter fra banen standsede for at blive klar over, hvor langt der var mellem de patruljerende tyskere. Vi havde stået stille en halv snes minutter, da der indtraf det for os særdeles lykkelige, at en fast tysk vagtpost rømmede sig i mørket kun tre meter fra os. Aldeles hurtig, men med front mod vagten, trak vi os tilbage. Der var ikke mere at gøre der.

Vi måtte så forsøge en fremrykning over åben mark, tyskerne blinkede fra banen med deres lygter og skød her og der; men netop i aften var det vasentligt at komme frem.

Langsomt, foroverbøjede og med de afsikrede MP'er parate nærmede vi os igen dxmningen, og denne gang syntes det at skulle lykkes. Vi så allerede den lysere himmel over dxmningen. Jeg tror ikke, at nogen nogensinde er blevet mere overraskede end vi, da der igen engang ganske uventet dukkede en tysk vagtpost op umiddelbart $i$ nærheden af os. Hvorfor han ikke skød, forstår vi ikke - og dog han havde formodentlig set, at vi var tre, og han havde været dårligt stillet, om han havde givet ild. Men igen en gang måtte vi trække os tilbage. Da vi tæt op til en gård forsøgte tredje gang, gik det os på samme måde. Der røbede tyskerne sig dog tidsnok til, at vi i ro og mag kunne komme bort. Faren syntes allerede at være drevet over. Vi var vel kommet ca. 150 meter fra dxmningen, da vi blev klar over, at tyskerne dog ikke havde varet ganske ligeglade med vor nærværelse. En raket gik til vejrs, og egnen lå badet $i$ lys. Vi var lykkelige, at vi ikke befandt os ude på den bare mark; vi havde i så fald afgjort været fortabte; omkring 100 geværer havde kunnet forfølge os. - Da raketten slukkede, tog vi hjem.

Omtrent på samme måde gik det Langetved-gruppen.

Langetved-gruppen angreb ostbanen omkring Bykjær enge syd for Farris. Også den var klar over den stærke bevogtning, og den var derfor kun rykket ud med tre mand. Over en bæk var de kommet frem til et højdedrag, der stødte op mod banen. Vagterne passerede 
forbi i deres umiddelbare nærhed. Til deres overordentlig store overraskelse opdagede de, at der pludselig også gik tyske soldater bag dem. Så var de åbenbart sluppet igennem $\mathrm{i}$ et heldigt øjeblik. De lå ganske rolige med front mod linjen. Alligevel må de være blevet opdaget, og de blev råbt an. Tre soldater kom med lommelygter ned mod dem. Parolen lød på først at skyde i allersidste øjeblik. De tre mand lå og ventede og havde hver sin tysker på sigtekornet. Tyskerne kom nærmere. Gruppeføreren kunne se sine kammeraters MP'er blive belyst af soldaternes lygter; men som sagt gjaldt det om først at skyde $\mathrm{i}$ yderste øjeblik.

Fem meter fra gruppen drejede tyskerne uventet af, snakkende og åbenbart uvidende om, hvor tæt døden havde været inde på livet af dem. Gruppen ventede endnu nogen tid. Til deres ærgrelse passerede der ikke mindre end fire tog, men alligevel måtte de indse, at ethvert fremstød var umuligt. De måtte endda være glade, hvis de slap fra stedet med livet. Det lykkedes dem. De fulgte en bxk, og de slap bort.

Forgæves havde vi altså forsøgt at opnå resultater. Nu oprandt "Langelænder-ordren «s sjette dag, og den folgende skulle vi indsende rapport. Det ville være trist at skulle melde: Intet udrettet. Tanken om at likvidere vandtårnet på Brørup station kom os til undsætning.

En hurtig rekognoscering fortalte, at også stationen var skarpt bevogtet; der var på den anden side ikke nogen fast vagt indenfor rækværket, der omgav tårnet, og der førte en udvendig stige direkte op til cisternen gennem en luge. Det skulle altså være praktisk muligt at komme derop.

Vi beregnede cisternens omkreds til ca. 12 meter. Fire bomber a $2 \mathrm{~kg}$ blev giort fast til cordtex, og fire 2-timers blyanter med tilhørende detonatorer blev lagt ved. Forsøget skulle gøres. En mand brapte bomberne med rutebil til Brøruv station. Han havde dem $i$ en kuffert. Det var den 13. februar, en ordinær vinterdag.

Vi spiste middag på hotellet; det var velforsynet med tysk militær. $\mathrm{Da}$ vi var færdige, var der en time, til offensiven skulle begynde. En ung tvsk officer spillede klaver; han spillede godt: overordentlig godt: hans kammerater sad tavse og hørte på. og vi fik samtidig en naturlig grund til at blive siddende den tid, der var tilbage; vi forstod, at alle i stuen skulle på vagt — også den nydelige og dygtige 


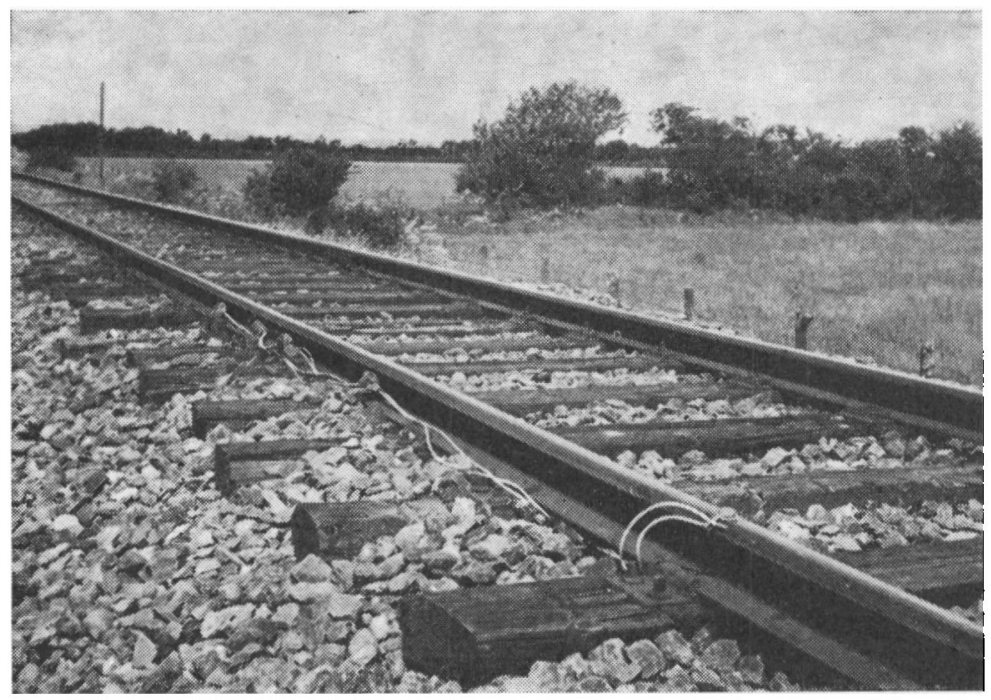

Forberedt sabotage på strakningen Vamdrup-Farris. Man ser tydeligt cordtex-baindet. (Aase Rosendahls arkiv).

pianist skulle ud på banen for at holde danskerne borte. Vi blev siddende nogle øjeblikke, efter at de var gået. Der var altsă vagtskifte nu. Vagterne var udhvilede og friske.

Klokken lidt før otte gik vi. Månen var ikke stået op; men det var desværre stjerneklart. Manden, der skulle op ad den udvendige stige, ville kunne ses mod den klare nathimmel.

Men det fik være.

Det tyske feltpoliti gik langsomt, men afgjort hørligt ned gennem byens gade. Ved viadukten blev enkelte standset og undersogt. Vi gik hen langs banen, til vi fandt en høj mur om en have, og der gik vi ind og gjorde de to maskinpistoler klar. Bomberne kom $i$ en havasack, bombemanden fik en 6,35'er samt en lille blå lommelampe. Således udstyret skred de tre mand til værket. De to med MP'erne gik forrest. Over for stationen lå et lavt hus lidt tilbage i husrækken. Det frembed skygge. Der tog vagterne opstilling. Bombemanden derimod fortsatte. Han gik en tur forbi vandtårnet, glædede sig over, at der ikke var nogen fast vagt på gaden, og kom så tilbage og gik ind på perronen for at se forholdene dér. Jo, der var to vagter 
under tårnet. I det samme hørtes et tog, der nærmede sig. Det måtte give en chance.

Bombemanden trak sig lidt tilbage i stationsbygningens skygge.

Lidt barnlig søgte han hjælp ved at tæenke på Tordenskjold. Tordenskjold måtte virkelig have levet, og ham ville det åbenbart ikke have generet at gå her og lade som ingenting. Det ville nxppe heller have generet ham at springe over rxkværket dér og op i tårnet, selvom vagterne stod på den modsatte side. Kedeligt, at de kunne se stigen, hvor de stod. Det var nok, fordi en dame havde skrevet til ham om Tordenskjold, at han tænkte på ham.

Hvilket Guds under, at et godstog kom ind netop nu.

Lokomotivet standsede udfor vandtårnet. Javel. Det var naturligt nok; der stod jo vagtposten. Der kom samtidig et tog fra den anden side - utroligt - nærmere og nærmere. Et helvedes spektakel var der. Nu var det inde - nu var chancen der - og den kom måske aldrig mere igen: Et svært lokomotiv pustede få meter fra ham, et andet kom larmende forbi. Bombemanden sprang over rxkvxrket, løb gennem buskadset hen til vandtårnets fod og lâ stille.

$\mathrm{Nej}$, der var ingen vagt inde mellem buskene heller, og ingen udefra havde set ham. Han gik forsøgsvis to skridt op ad stigen. Der var langt mellem trinene. Han så, der stod to tyske soldater på perronen, men de var optaget af lokomotivet. Pludselig kaster maskinen en masse damp fra sig. Vagterne bliver skjult. Røgdakket må vare nogle sekunder; men det er også nok. Bombemanden går til vejrs og forsvinder ind ad lugen med sin havasack på ryggen.

Ingen har opdaget ham.

- Han har aldrig før været $i$ et vandtårn. Han hører, det drypper fra hanen ned i bassinet - regelmæssigt og roligt, som om intet usædvanligt var på færde. Hver dråbe drypper lydeligt - der er god akustik $\mathrm{i}$ cisternen! Disse dryp virker beroligende. Han tager tid til at orientere sig og går forsigtigt rundt om den store beholder. Uheldigvis ramler han mod en lem i mørket, fandens til spektakel. Han lytter. Nej, der sker intet. Han tager sig mere i agt. Først bagefter hører han, at lyden har gjort vagterne nedenfor opmærksomme, og med lommelygterne undersøger de jorden under tårnet. De to MP'er på den anden side af gaden løftes opmærksomt; de følger med i, hvad der sker ved tårnets fod. Tyskerne falder imidlertid til ro igen. 
Bomberne må klemmes fast nede ved cisternens bund. Det er besværligt at få cordtex lagt omkring beholderen. De to paralleltløbende stykker à 12 meter er filtret godt ind $\mathrm{i}$ hinanden, og arbejdet må ikke fremkalde støj.

Bombemanden farer forskrækket sammen, da et vandfald pludselig slippes løs over ham. Det fosser og larmer. En automatisk udloser er åbenbart begyndt at fylde cisternen, efter at lokomotivet dernede har fået vand. Men det er vel ordinært, ganske ordinært sådan noget må da ske $\mathrm{i}$ et vandtårn hver dag mange gange, og det er egentlig også rart, han får jo derved starre bevægelsesfrihed men en frygtelig larm er det alligevel. Omsider - men det tager over en halv time - er bomberne lagt omkring beholderen og rede til at blive klemt fast og få påsat tidsblyanter.

Han binder cordtexenderne sammen, så at bomberne kan holdes på plads. Så ligger han en tid og arbejder med overkroppen udover lugen og med den blå lommelampe $\mathrm{i}$ munden. Han fastgør tidsblyanterne med isolerbånd. Tyskerne snakker livligt nedenfor. Den ene af soldaterne har abenbart moret sig godt aftenen før; han fortæller og fortæller. Det er mørkt; bombemanden glæder sig over den lille fosforescerende stribe, der viser sig på isolerbåndet, når det slipper rullen. Det ser smukt ud. Som han ligger her og afslutter sit arbejde med armene over hovedet, kommer han til at tænke på Hemingways Robert Jordan, da han skal sprænge broen $i$ luften. Der er dog den væsentlige forskel, at meden; Robert Jordan har travlt, har bombemanden gudskelov uendelig god tid. Masser af tid. Han kunne blive der til i morgen tidligt, om det skulle være. Blyanterne bliver omhyggeligt gjort fast til cordtex - fire stk. for en sikkerheds skyld. Det får et ekstra stykke isolerbånd. Bombemanden går flere gange rundt om cisternen; han vil sikre sig, at alt er $\mathrm{i}$ orden. Bomberne presses hårdt ind mod beholderen, og cordtexstykkerne lægger han omhyggeligt side om side, så de ikke skxrer hinanden over under sprængningen. Så er alt $i$ orden. Det er en dejlig følelse. Han trykker blyanternes kobberrør i stykker, tager sikkerhedspindene ud og stikker dem i lommen. Nu begynder mekanismen at virke. Efter dette er der måske knapt så hyggeligt i tårnet som før. Det vil trods alt være rarest at komme ned. Opholdet $i$ tårnet har varet en time.

Skade, at man ikke kan se med tæerne; de skal nødvendigvis ned 
først. Bombemanden må gøre forsøget. To trin nede opdager han, at nogen kommer på fortovet. Han må op igen. Han venter. Næste gang går det bedre. Der synes at være en uendelig afstand mellem trinene. Men han kommer ned på jorden. Hvor er vagten? Bombemanden ligger og venter - der er ingen. Så forsøger han at nå hen til rækværket. Der er kun nogle få meter. På halvvejen ser han den tyske soldat på den anden side af tårnet. Hvad er der at gøre? Han må løbe risikoen; han springer over rækværket og løber over gaden mod hjørnet. I skyggen tager han hat og jakke af; han vender hurtigt om og går $i$ en anden, rolig gangart tilbage forbi sine to kammerater, der uden at sige noget følger ham. De går hen mod haven, hvor kufferten er gemt.

Der er mere end to mil at gå hjem. På hjemvejen - hos en tilfxldig vognmand - alarmeres Vagtværnet, der anmodes om at advare folk $i$ nabolaget.

Vi forlader den chokerede mand, der så beredvilligt har stillet sin telefon til vor rådighed, og fortsætter ud ad vejen. Enhver bil får os til at søge ind på markerne. De to timer går hurtigt. Tiden nærmer sig, da bomberne skal sprænge. Det er meget forståeligt, hvis de ikke er ganske præcise - temperaturen er omkring 0 . Tiden går, men der høres intet ude fra horisonten mod nord. Så er også nok tyskerne blevet alarmeret og har opdaget, hvad der var galt. De har formodentlig pillet det hele vak; vi skulle aldrig have ringet til Vagtværnet; vi er for humane - dårlige soldater.

Langt borte, to timer senere, står vi og venter.

På en høj bakke nær vor by står vi usædvanlig triste til mode, trætte og tavse. Vi kigger mod nord. Er natten spildt? Natten er spildt. Horisonten er mørk og rolig. Vil der ikke ske noget? Aldrig glemmer vi, at der pludselig farer et stærkt lysglimt mod himlen, et eller andet brendende slynges til vejrs, lyset flammer voldsomt op og slukkes så. Få sekunder efter fortæller en voldsom detonation, at vort arbejde alligevel lykkedes. Klokken var da 23,30.

$V i$ springer omkring af henrykkelse - begejstrede. Hele den nordlige himmel lyser nu op - tyskerne skyder som gale; karabin- og maskingeværild blinker hele den nordlige horisont rundt; lysraketter går til vejrs; det er et nydeligt syn - og rart at have på afstand.

Efter at vandtårnet var borte, kunne lokomotiver, der før trak 
tog, der vejede 600 tons, kun trække tog på 300 tons mellem Esbjerg og Lunderskov. Således forblev det til krigens afslutning.

Efter vandtårnssprængningen hvilede vi os til natten mellem den 26.-27. februar - altså i næsten 14 dage. I mellemtiden havde vi modtaget en del pistoler (elefanter), og vi havde været behjælpelige med transport af sprængstof. Samtidig passede vi vore fremstød på papirfronten, idet vi sendte en hel del opråb ud over hele Jylland og Fyn, adresseret navnlig til danske landmænd. Denne virksomhed var begyndt i slutningen af 1943 og omfattede flere skrivelser. Det mest omfattende arbejde var novellen "Havet tier « af den franske forfatter Vercors, som vi duplikerede i sommeren 1944, og som blev sendt ud til alle højskoler og landbrugsskoler. Restbeholdningen ca. 1000 eksemplarer blev af "Ringen " sendt ud til alle foreningens tillidsmænd over hele landet til fordeling.

Regionsledelsen forberedte sidst $\mathrm{i}$ februar en omfattende ødelæggelse af det sønderjyske jernbanenet: Alle grupper skulle rykke ud med et særligt stort antal bomber for at foretage almindelige sprængninger.

- Der er travlhed i det værelse, hvor bomberne laves. 30 dobbelte bomber -60 bomber ialt - er mange. En mand har til opgave at klippe cordtex til og sætte forladningerne fast - en anden at xlte bomberne omkring forladningerne og pakke dem godt ind $\mathrm{i}$ vandtat stof eller papir. Vi brugte denne gang forsøgsvis cellofan. En tredje sætter detonatorerne fast $\mathrm{i}$ tidsblyanterne. Det er alt $\mathrm{i}$ alt dejligt arbejde; det har en forjættende stemning over sig, bomberne skal bruges næste nat.

$\mathrm{Ni}$ mand tager af sted $\mathrm{i}$ to biler. Ingen glemmer stemningen $\mathrm{i}$ en vogn, der en sådan aften kører ud i mørket.

Vi véd, at vi kan blive standset og undersøgt. I så fald gælder ingen pardon - vi må skyde først. Med maskinpistolerne på skødet følger vi med $i$, hvad der kommer ind $i$ den lange lyskegle foran vognen. Føreren har en $11 \mathrm{~mm}$ pistol hos sig; også han er spæendt. Vinduerne er rullet ned, skønt det er koldt.

Vognen standser uden for Føvling. To mand står ud, og vognen fortsætter gennem landsbyen til et aftalt sted. Vi skal hente MP'er på Føvling kirkeloft til folkene $i$ den anden vogn. Vi kender snart Føvling ved nat. Det er en meget diskret landsby. Den har ikke engang en almindelig R-gruppe; men det er også lige meget, blot den 
sover, når vi kommer. Er man først inde på kirkegården, kan man være så temmelig tryg. Overtroen beskytter. Gennem buksbom og over ligsten kommer vi hen til tårnets gamle sidedør. Dens lås er vi én gang for alle blevet fortrolige med. Vindeltrappen derimod er hver gang forbandet smaltrinet og snæver og snavset. Over et smalt uroligt bræt når vi ind til loftets første hvælving. I lommelampens blå skær ligner dette kirkeloft et særdeles dødt bjerglandskab. Vi kryber forsigtigt op og ned og ned og op, til vi kommer hen over koret; der er vort depot. Magasinerne bliver fyldt - MP'erne sat sammen, og så trækker vi os tilbage.

Bilen kører os ad små biveje til et sted ca. 800 meter fra linjen. Begge vognene parkeres letsindigt nær vejen, og 300 meter længere fremme bliver blyanterne og detonatorerne sat fast på bomberne. To mand bliver sendt frem for at rekognoscere. Der er ikke en tysker at se på linjen.

Desværre er en stor måne forlængst stået op. Vi har den endda i ryggen. Fra jernbanen vil vi kunne ses på lang afstand. $3 \times 3$ mand rykker frem. Hvert hold har en bombemand, der bærer 10 dobbeltbomber. Et par hundrede meter er det nødvendigt at følge vejen. En bil kommer kørende; men alle når at komme i læ bag en lade. Få minutter efter kan processionen fortsætte igen. Det er en tåbelig måde at rykke frem på. Den forudsætter absolut, at tyskerne ikke er ude i nævneværdig grad.

Det er ganske lyst. Bombemændenes hvide cordtex kan ses langt bort, og skulle man undgå at blive opmxrksom på den, vil man $\mathrm{i}$ hvert fald se bombernes blinkende cellofanindpakning, der lyser $i$ måneskinnet. En julemand ligner det, der velforsynet med pakker kommer gående hen ad vejen. Ved et hegn får en mand pludselig den idé, at der står vagt bag den nærmeste gård. Man gør holdt, og sagen undersøges. Men der er ingen vagt. Snart er man velbeholdne ved linjen. Tre mand går mod øst, tre ligefrem og tre mod vest. To sørger for dækning, mens den tredje arbejder oppe på skinnerne.

Omkring hvert stød lægger han en dobbelt-bombe, der ødelægger to skinner. Bomberne legges hurtigt ind under skinnerne, sten og grus lagges op om dem, og blyanterne trykkes. Efter ca. otte minutters forløb er de 60 bomber lagt ud. Ingen vagt er iagttaget.

Føvling kirkeloft så altid mere venligt ud, når vi afleverede våbnene, end når vi hentede $\mathrm{dem}$, og af én eller anden grund beregnede 


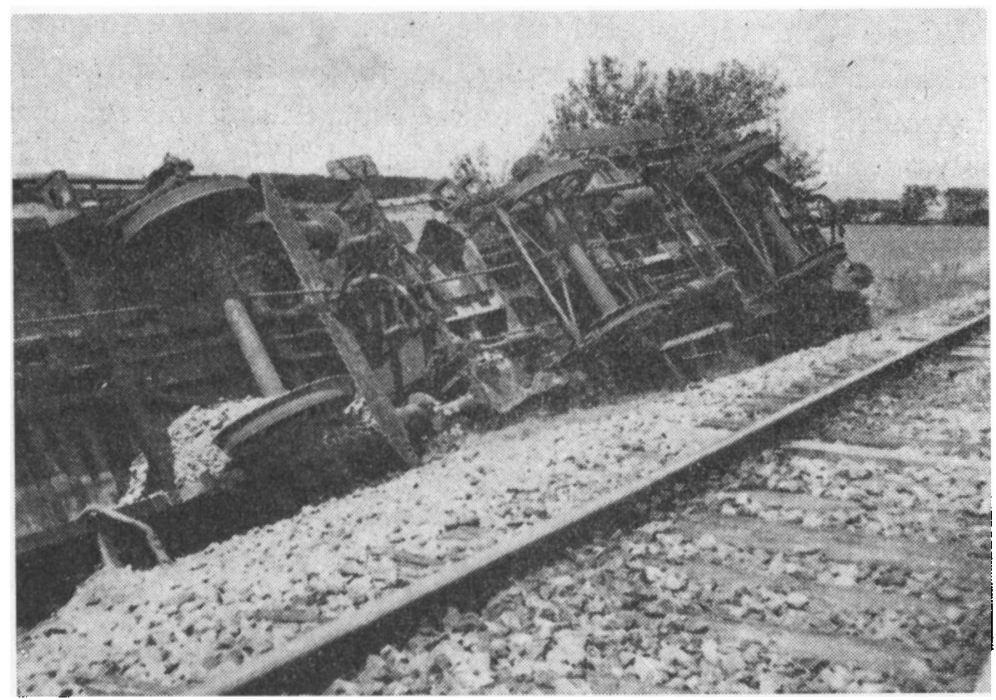

Fuldbyrdet subotage på Lunderskot-Vamdrup-Farris-linjen. (Aase Rosendahls arkir).

vi chancen for at møde patruljer til at være væsentligt mindre på hjemturen end på udturen. Humøret var sxerlig højt under dette tilbagetog, fordi vi efter en halv times forløb hørte, at bomberne begyndte at springe. Natten igennem sprang de. Først ved 5-tiden om morgenen holdt de inde, og så sov vi ind overmåde vel til mode.

Resultatet blev 58 sprængninger, det største antal sprængninger, der er foretaget på en vigtig jernbanestrækning her $i$ landet. En fredelig, men effektiv aktion var altså tilendebragt.

Et stort fremstød skulle Langetved-gruppen foretage på østbanen natten efter. 30 dobbelt-bomber havde de gjort klar, og seks mand stærk rykkede de ud.

De havde valgt sig som angrebspunkt Bastrup skov nord for Farris. Langetved-gruppen cyklede altid frem til målet. Således også denne gang. I en grusgrav tæt ved linjen havde de lejlighed til at gøre bomberne færdige, og derfra skulle de rekognoscere. En mand meldte, at der var indtil 5 minutter mellem hver patrulje. Og han 
havde ingen faste vagter set. Man blev enige om i hvert fald at sikre anbringelsen af 10 dobbelt-bomber, og for at denne kunne finde sted så hurtigt som muligt, veg han ikke tilbage for straks at klemme tidsblyanterne og tage sikkerhedspindene ud. Det var så at håbe, at blyanterne ikke havde funktionsfejl, men at de virkelig ventede en halv time, inden de sprang. Forsigtigt krøb man frem fra grusgraven.

Månen var stået op, og landskabet lå fuldt oplyst. Et hegn førte en god del af vejen frem mod linjen, og $\mathrm{i}$ læ af det mavede man sig frem. Gruppeføreren lod de øvrige blive tilbage, mens han selv gik frem for at vurdere stillingen. To tog passerer imens - adskillige vagter ligeledes - og inden han ser sig om, opdager han, at hans gruppe ganske lydløst er nået helt frem til ham. Man spreder sig så på marken, rede til at dxkke gruppeføreren, der skal op på dxmningen.

Bombemanden er netop kommet over hegnet, $\mathrm{da}$ en maskinpistolsalve farer ud fra en busk en halv snes meter henne. De seks mand reagerer hurtigt, men yderst forskelligt. To mand går amok, og slagne af rædsel løber de tilbage - et fint măl for tyskernes karabiner. Bombemanden mener imidlertid, at han intet har med den sag at gøre; hans job er det at lægge bomberne, og det gør han ugenert af, hvad der sker. Denne optraden giver en del af de øvrige courage, i sxrdeleshed da busken igen spyr ild. En mand tømmer ubetænksomt et helt magasin $i$ busken, en anden læager sig roligt ned og giver den tyske MP'er to skud ad gangen - skifter magasin - og fortsætter, indtil busken tier. Selv bliver han kun ramt i støvlehælen.

Under skydningen har de tyske vagter forladt linjen; - der er stille. Månen sender sit starke, hvide lys ned over de tre mand, der ganske hurtigt trækker sig tilbage mod en bakkekam. De hører tydeligt vagten bag busken klage sig. Nxppe er de kommet $i$ håndgranat eksploderer bag dem, én til og flere endnu, og fra linjen - navnlig i nærheden af et vagthus - er der voldsom skydning; men tyskerne skyder for højt. Skydningen afbrydes uventet af detonationen fra en bombe, der springer. Det var altså på høje tid, de fik dem anbragt. På hjemvejen møder de de to mand, der tog flugten. De er opskræmte som løbske heste. Den ene kan dårligt tale; de vil aldrig ud mere.

Statsbanernes rapport meldte, at syv skinner blev udvekslet. 
Aftenen efter denne heldige nat var der to mand, der kom ud for en speciel opgave. Roddings "Ring «-repræsentant havde opsamlingssted for nedstyrtede allierede flyvere, og dagen for var en flyvende fæstning styrtet ned over Gram. Vi var tilfældigvis til stede og så de hvide faldskærme folde sig smukt ud mod den skyfri, blå himmel. Den tomme maskine fortsatte sydpå forfulgt af de knitrende tyske jagere, der til slut skød den ned. Ni allierede flyvere landede så godt som uskadt på jorden. Det er Gram-gruppernes store fortjeneste, at de fik fat på to af disse flyvere og bragte dem i sikkerhed. I Gramgruppernes historie må der sikkert findes en redegørelse for dette fremragende stykke arbejde.

Imidlertid kom flyverne til Rødding den følgende aften. Det var amerikanere; den ene var en ganske ung landmand (mekanikeren $i$ maskinen), den anden sølvsmed (navigator $\mathrm{i}$ maskinen). Vi skaffede dem alle tøj, fik dem $i$ aftenens løb fotograferet og forsynet med legitimationskort. Dagen efter skulle vi fragte dem til Fredericia, hvor opsamlingsstedet var for vort distrikt. Amerikanerne var nervøse. De havde aldrig set en tysk soldat før, skønt de lange havde været $\mathrm{i}$ krig. Til fods gik vi $-\mathrm{i}$ to hold - ud gennem Rødding. Her skulle vi møde en privatbil og med den køre til Jels. Ved det store Jelskryds var der lykkeligvis ingen vagt. Længe ventede vi i Jels på rutebilen. Vi havde lart amerikanerne at sige $* \mathrm{Ja}$, ja*, og vi tiltalte dem kun i sætninger, der krævede bekræftende svar. I Kolding tog vi ind hos en prxst, der forsynede os med middag. Det viste sig, at vi ikke kunne komme med rutebil til Fredericia, den medtog kun passagerer til mellemstationerne. Dagen var togløs.

Det lykkedes os at komme med et godstog. Togets eneste passagervogn var stopfuld af tyske soldater, hvilket tydeligt generede amerikanerne en del, men de vænnede sig vist også til det.

$\mathrm{Vi}$ var ondskabsfulde, da vi tipsede, at systemet ville svigte; men det svigtede faktisk. I Fredericia havde Gestapo forårsaget en hel del uorden, og manden, der skulle tage imod os, turde ikke have med os at gøre. Det var ubehageligt, navnlig for amerikanerne, at gå rundt en hel eftermiddag $i$ Fredericias gader. Vi havde fået en anden adresse; men den svarede ikke før kl. $10 \mathrm{om}$ aftenen. Hvad skulle vi gøre? $\mathrm{Kl} .7$ gik vi i biografen og så en ualmindelig smuk dansk film. Udenfor greb en mand os $i$ armen. Han havde sørget for noget at spise. Vi skulle henvende os til værten $i$ den og den 
restaurant, og det gjorde vi gerne omgående. Gennem lange gange blev vi ført til et fjernt liggende værelse. Værelset var ganske mørkt, formodentlig var der skodder for vinduerne. Nogle bænke stod vist nok stablet op i den ene ende af stuen, ellers så vi kun et bord og nogle stole. Over bordet hang en kegleformet lampeskærm, der sendte et stærkt lys ned over et mangefarvet smørrebrødsbord. Et spektrum af farver. Øl, snaps og tobak kransede herlighederne. Udenom i rummet var det ganske mørkt. Amerikanerne livede op ved dette syn, og vi spiste alle godt.

Kl. 10 gik vi til den før omtalte adresse. Også her var der vanskeligheder. Konen var syg og nervøs, og vi kunne ikke blive lukket ind. Et kraftigt svar gjorde det klart, at manden måtte skaffe os logi, og det med det samme. Så gik turen igen gennem mørke gader, hvor tyske patruljers tramp af og til gav genlyd. Ved et højt hus standsede vi; en mand i pyjamas kom frem på tredje sal, og snart stod vi $i$ et lille tjenestemandshjem; men heller ikke de havde plads til os. Imidlertid fandt de en seng på et loftsværelse, og med den måtte vi klare os. Amerikanerne sov i sengen på loftet, og vi lagde os på gulvtæppet $\mathrm{i}$ stuen.

Den næste morgen sikrede vi os, at alt var $\mathrm{i}$ orden til den videre transport af amerikanerne - og vi tog hjem.

Vi hørte senere, at de begge $\mathrm{i}$ god behold var kommet til Sverige.

Den 2. marts var nogle folk fra Rødding igen $i$ arbejde mellem Brørup og Holsted. Bomberne sprang klokken 4 om morgenen, og 6 skinner måtte udveksles.

Allerede den 6. marts melder statsbanerne igen om sabotage på vor strækning på østbanen. Beretningen siger: Mellem Farris og Sommersted. Kl. 0,45 sprængning under dansk godstog; én postvogn afsporet, en skinne udvekslet. Trafikken genoptaget kl. 9,40«. - Iflg. statsbanernes beretning er der altså ikke sket stort. Ikke desto mindre var det en ekspedition, hvor alle - i hvert fald i den ene gruppe - var særdeles veloplagte, og hvor der var høj stemning, fordi man trods voldsom bevogtning dog nåede hjem med resultat.

Der var ti mand $i$ arbejde, fem fra Rødding og fem fra Langetved. Man havde besluttet sig til to fremstød, et over Bastrup mose og et 


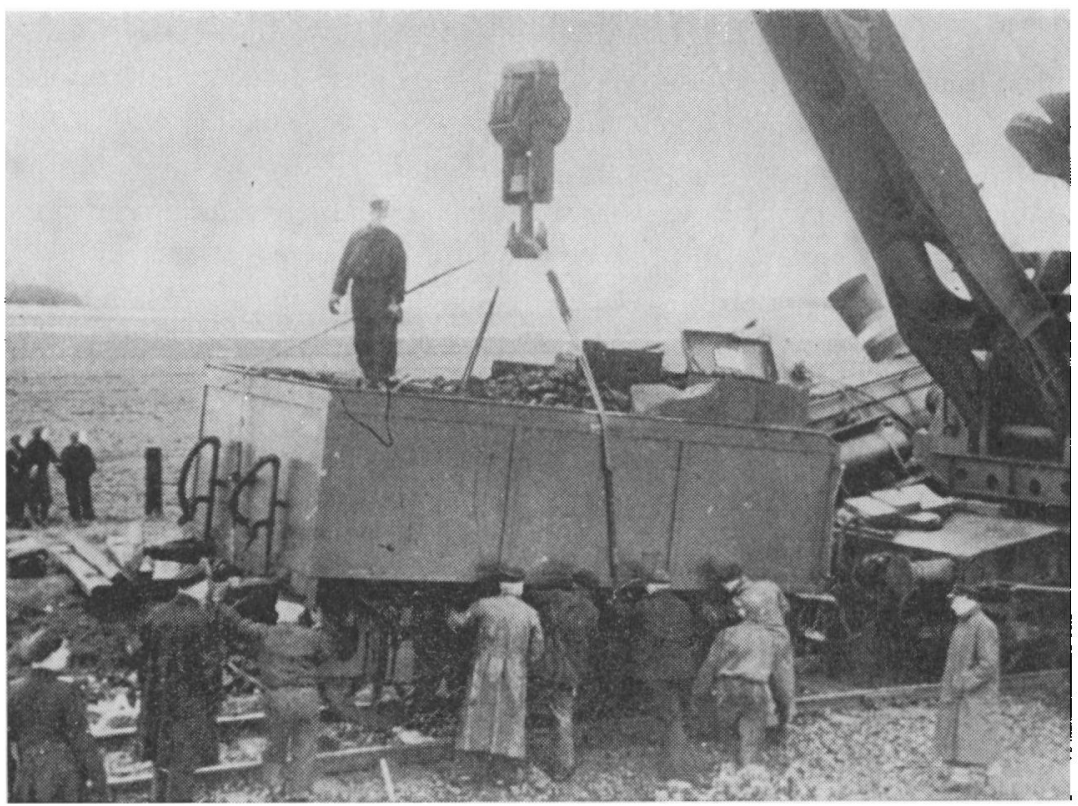

Et trals job. Danske jernbanefolk $i$ arbejde med korekran efter sabotage på strakningen Lunderskov-Vamdrup-Farris. (DSB jernbanemuseet).

noget sydligere. Temperaturen var under 0 grader. Ikke blot betød dette, at man fandt det koldt at færdes i mørket; men hvad værre var: Jorden knasede, når man gik hen over den. Af denne grund, og da som omtalt linjen var under skarp bevogtning, blev det nordlige angreb helt uden resultat. Anderledes gik det derimod for gruppen mod syd. Den blev flere gange slået tilbage, ikke af geværild, men af forkølede vagters højlydte hosten; men den lette frostluft $i$ forbindelse med de gunstige vilkår, som morket frembed, ansporede de fem mand til at prøve igen og igen. To afsporingsladninger havde de med sig, og de skulle helst anbringes. Ved at smide skoene lykkedes det virkelig til slut bombemanden at nå frem til hegnet ved banelegemet og også at få den fornødne dxkning frem. Men bedst som han ligger og arbejder på sporene, kommer vagterne til. Den frosthårde jord er dog ikke blot på tyskernes side - han hører, de kommer, og han forsvinder. Imidlertid bliver han jo ikke færdig med sit arbejde, så da tyskerne er borte, må han op på linjen igen. Heldigvis var det så mørkt, at tyskerne end ikke opdagede det hvide 
cordtex, der strittede frem mellem svellerne. - Indtil flere gange blev bombemanden således forstyrret; men efter hver gang kravlede han igen op på dxmningen, og endelig blev han så færdig. To afsporingsladninger la $\mathrm{da}$ parate til at modtage det nxste tog. Forhåbentlig blev det tysk, og forhåbentlig blev det en vældig transport.

Gruppen forsvandt om bag en gård for at afvente resultat.

Der gik sjældent lang tid mellem togene på østbanen. Heller ikke denne gang ventede man længe, før en fjern rumlen meldte, at et intetanende tog kørte sin formodentlig voldsomme skxbne $i$ møde. Det kørte langsomt, altså var det et godstog. Virkningen havde naturligvis været større, om det havde været et orlovstog.

Gruppeføreren løber frem til et hegn, da han hører toget komme. Et valdigt lysglimt tegner konturerne af et dansk godstog. De to afsporingsladninger går tilsyneladende samtidigt, og det ser ud, som om sprængningen slår op igennem to vogne og antænder taget. Det brænder lysende $i$ natten - og så forsvinder han. På hjemturen er humøret højt. Det har været en vanskelig, men samtidig en billig tur, og det har åbenbart fået et nogenlunde resultat.

Hvorledes var humøret iøvrigt under disse sabotageaktioner? Ja, jeg tør sige, at hvert fremstød havde også i denne henseende sit eget ansigt. Det kunne være nervøsitet og uoplagthed, der gav stemningen sin farve; det kunne også, og det var uden tvivl det almindelige, være således, at stemningen var præget af, at man nu igen skulle ud - der var jo ikke andet at gøre - man havde én gang taget sin beslutning om at ville være med til at slå nazismen ned - og så måtte man håbe, at det gik. For hver gang blev man vel mere øvet; men man blev også for hver gang stadig mere klar over, hvor stor risikoen var, og hvori den bestod. Man har talt meget om sabotørernes mod, og de var vel modige; men den indstilling, den enkelte havde over for faren, kunne nok skifte fra aften til aften. I væsentlig grad var den betinget af, hvor udhvilet man var. Graden af mod er også betinget af, hvilket ansvar man har. Det støtter føreren, at han har førerens ansvar; det er ham, der må gå først (ikke ifølge teorien, men ifølge praksis) - og han gør det, fordi han véd, at det afhænger af ham, om gruppen overhovedet når frem. Man har spurgt, om mod overhovedet er en god egenskab. Der gives jo, hvad der på tysk er 
kaldt »ein Draufgänger «; han er modig; men dermed er åbenbart også alt sagt. Mod ser man vist helst velsignet af klogt og omtanke, før man ubetinget skænker det sin hyldest. Hos vore udmærkede medborgere kunne vi finde adskillige tilfælde, hvor manglende mod afholdt manden fra at hjælpe os. Han kunne sige det rent ud: "Jeg har ikke nerver til det - og jeg er ked af det«. - Jeg har aldrig hørt en sabotør tale på nogen måde nedsxttende om sådanne folk. Selvfølgelig ikke. Det blev blot konstateret, at således var det. Ingen vidste jo, hvornår det blev hans tur at stå overfor en prøve, som han ikke ville bestå. Men den, der talte store ord og dog ikke turde hente dem hjem, når det gjaldt, han blev foragtet dybt.

Endnu en ting skal nxvnes her $\mathrm{i}$ forbindelse med spørgsmålet om sabotørernes forhold til "de andre«. Det hændte jo, man mødte en højst uvenlig indstilling over for sabotagen. Det er nu bag efter ejendommeligt at konstatere, at det er en almenmenneskelig psykologisk lov, at kombattanterne har yderst let ved at komme til at hade nonkombattanterne. En foragtelig eller uvenlig bemærkning om kombattanternes kamp vil straks kalde det stærke had op i ham - og dette had kunne det være vanskeligt at beherske; $i$ almindelighed var det imidlertid nødvendigt at gøre det.

I slutningen af februar overtog bylederen i Rødding det førnævnte job som "Ring «-representant i regionsledelsen, hvilket navnlig førte rejser med sig rundt $\mathrm{i}$ regionen for at oprette grupper. Arkitekt Jensen, Rødding, overtog derefter Rødding bydistrikt som byleder.

Arkitekt Jensen (senere dæknavn Knud Petersen) havde været underofficer $i$ garden. Han var overordentlig velegnet til at være byleder og havde det store fortrin fremfor sin forganger, at han var særdeles praktisk indstillet, hvorfor han også uden for det egentlige bylederarbejde blev regionsledelsen til stor hjælp. Jensen var en stor, kraftig, blond, dansk type på ca. 30 år. Han var af væsen åben og enkel, men havde god forstand på og et sikkert greb om de ting, han tog sig af. Dertil kom, at han var overordentlig arbejdsom og ikke sparede sig selv for nogen ulejlighed, når det gjaldt om at klare de opgaver, der forelå. Som leder havde han underofficerens myndighed og tone, men på den anden side var han ikke uden den humor, der var en nødvendig betingelse for, at arbejdet kunne trives, her, hvor det drejede sig om frivilligt mandskab. 
En af de mest dramatiske nætter, Røddings $R^{1}$ folk oplevede, var natten mellem den 17.-18. marts. Denne nat skulle der finde fremstød sted mod alle banerne i Region III, og regionsledelsen havde ventet sig et smukt resultat. Regionsledelsen havde ganske vist fået nys om, at vagten de sidste uger blev forstærket lørdage og søndage, men dels var det ikke muligt at få dette forlydende tilstrækkeligt bekræftet $i$ tide, og dels var lørdagen af andre grunde meget gunstig for os.

Hovedstyrkerne fra Rødding skulle sammen med Langetved-folkene ud til østbanen. Så sent som hen på eftermiddagen var der kommet bud fra regionen, at Ribe måtte ligge stille, og at vi derfor skulle tage os af strækningen nord for byen. En mand blev straks om eftermiddagen pr. bil sendt på rekognoscering, og det blev besluttet, at tre mand skulle tage vest på; flere var der ikke at undvære.

Ved 10-tiden om aftenen tog de tre mand af sted vestpå i bil. En chauffør, en bombemand og to til dæekning med MP'er.

Aftenen indledtes med en punktering, men man tog det som et godt varsel. Alle store ting har jo store fødselsveer. Ad særdeles dårlige biveje nåede vi frem til en plantage, hvorfra der var en lille kilometer at gå til det sted, vi havde udset os. Bilen blev gemt mellem granerne; vi gjorde bomberne færdige, og bombemanden, der for første gang skulle prøve at anbringe ladningerne, fik 10 dobbeltbomber over skulderen. Imidlertid lyste det hvide cordtex så stærkt $i$ mørket, at vi valgte at give ham en frakke over skulderen; men desværre undlod vi at forvisse os om, at frakkens lommer var helt tomme. Bombemanden tog ligesom de andre en håndgranat $i$ lommen - ellers havde han ingen våben på sig.

I gåsegang - med en halv snes meters mellemrum - fulgte vi de smalle veje frem mod hovedlandevejen Bramminge-Ribe. Den skulle vi følge få hundrede meter og så støde frem mod banen. Planen var drøftet på forhånd. Inden længe når vi frem til den hvide cementhovedvej og følger den sydpå. Efter få minutters forløb standser den forreste for at forvisse sig om, at alle er med. Han får af den næste mand besked om, at bombemanden har reageret på hans fløjtesignal, og man fortsætter derfor. Den forreste mand undrer sig imidlertid over stadig kun at kunne høre én mand bag sig, og han standser endnu engang for at se bombemanden med egne ojne. $\mathrm{Nu}$ er det, det viser sig, at han er tabt. 
En mand sendes videre, og én går tilbage for at finde ham. Han er ingen steder at se. Man blinker med den blå lommelygte, fløjter og følger bivejen ud mod banen. Den vej, vi fulgte ud mod hovedvejen, fortsætter over denne ind mod linjen efter Hillerup. Muligvis er han gået ad den - men for megen rekognoscering her vil være farlig. I det hele er det en yderst uheldig situation, vi er kommet $i$.

Pludselig lyder der en voldsom detonation mod vest-nordvest. Den efterfølges af stærk skydning. Et øjeblik er der stille. Nogle råber. Så skyder tyskerne igen. Manden, der blev sendt sydpå, kommer tilbage.

Det er uvist, hvad der er sket. Det er næppe håndgranaten, han har brugt. I så fald havde der også været forudgående skydning. Håndgranaten ville han kun have anvendt $i$ selvforsvar. Snarere er der sket det, at han har trådt $i$ en detonator, og bomberne er så gået af. I så fald er han dræbt på stedet. Mod dette taler, at detonationen nok var kraftig, men ikke så kraftig, som den havde været, hvis ti bomber var gået af samtidig. Det er ganske uklart, hvad der er sket.

Imidlertid er der jo den mulighed, at han er såret og ligger og trænger til hjælp. Vi må derfor hen til stedet. Nu er der blevet stille - ubehageligt stille. Vi går ikke på selve vejen, men på markerne langs denne - $\mathrm{i}$ læ af et hegn. Ergerligt, at vi kun er to. 100 meter fra stedet gør vi holdt - rykker nærmere, lytter; der er ikke en lyd, heller ingen, der klager sig - vi venter. Det bliver tyskerne, der først taber tålmodigheden. De har et eller andet for derhenne. De taler højlydt sammen. Der er en syv-otte stykker. De ligger ved et hus; en gård har de på den anden side af vejen. Vi rykker lidt nærmere, men også kun lidt. Nu synes det, som om tyskerne vil ned mod os. Javel, så er der ikke andet at gøre. Vi gør front mod vejen og er rede til at modtage dem. Vi er nervøse, men der er ikke andet for. To mod hvor mange?

Men tyskerne bliver ved deres hus. Vi har ikke dristighed og erfarenhed nok til at storme det. To MP'er synes os for lidt, og ingen klager sig derhenne. Muligvis er vor bombemand taget til fange. Vi må derfor have bud hiem - det går ikke i nat at samles på det sædvanlige sted. Gestapo kunne komme først.

Vi trækker os tilbage til bilen. Chaufføren er urolig. Han får bud om at køre hjem og advare de øvrige. Vi to andre må så blive for at se, om noget nyt indtræffer, så vi måske kan være vor kammerat til hjælp. Situationen er meget mork. 
Da vi igen når frem til hovedvejen, er tyskerne der. De afpatruljerer cementvejen. Vi føler os yderst magtesløse. Vi han ikke indlade os i noget resultatrigt slagsmål mod så mange. Men hvor er vor kammerat?

Kl. 41/2 om morgenen må vi give op. Det er ved at blive lyst, og vi skal jo gå hjem. Det blev et meget trist tilbagetog. Vi måtte anse vor kammerat for tabt, og hele vejen tænkte og talte vi sammen under den forudsætning.

Ved Kalvslund skole kommer en mand ud fra gymnastiksalen. En tysk soldat? Han må have set, at vi gik med MP'erne over skuldrene. $\mathrm{Vi}$ forsvinder og må huske på, at vi jo ikke endnu er kommet helskindede hjem. Ved "Tornumgård" ringer vi hjem efter en bil - og vor chauffør henter os.

Nxppe nogensinde før har vi oplevet en sådan overgang fra sorg til glæde som hin morgen ved »Tornumgård«. Vor kammerat var kommet hjem! - for ganske få minutter siden!

Det var en ubeskrivelig oplevelse - vi var ovenud lykkelige.

Vi så ham ikke den morgen. Han var straks taget hjem for at berede sin tilværelse "under jorden «. Hans legitimationskort var jo blevet på valen; men vi fik senere at vide, hvad der var hændt ham. Han var ganske rigtigt, efter at være kommet til hovedvejen, gået lige ud mod Hillerup, d. v. s. ind mod banelinjen. Han hørte nemlig skridt, der gik ad den vej, troede det var os og fulgte dem. Ved den første gård på højre hånd standser imidlertid skridtene. Det viste sig at være en tysk soldat. Han spørger ham om legitimationskort. Bombemanden lader roligt bomberne glide ned fra skulderen til jorden med frakken ovenpå, og samtidig med, at han rxkker legitimationskortet frem, gør han sin håndgranat klar $\mathrm{i}$ den venstre bukselomme. Sikringen svipser imidlertid for ham, og han må derfor handle hurtigt. Han kaster håndgranaten for fødderne af tyskeren og lober. Ved et under bliver han ikke selv ramt. Tyskeren rammes derimod $\mathrm{i}$ det ene ben, men bliver ikke dræbt. Bombemanden har ejendommeligt nok ikke selv hørt detonationen, skønt den gav genlyd over hele egnen. Ad en stor omvej kom han hjem.

I en måned derefter gik vi hjemme altid omkring med en håndgranat og en amerikansk $11 \mathrm{~mm}$ i lommen. 


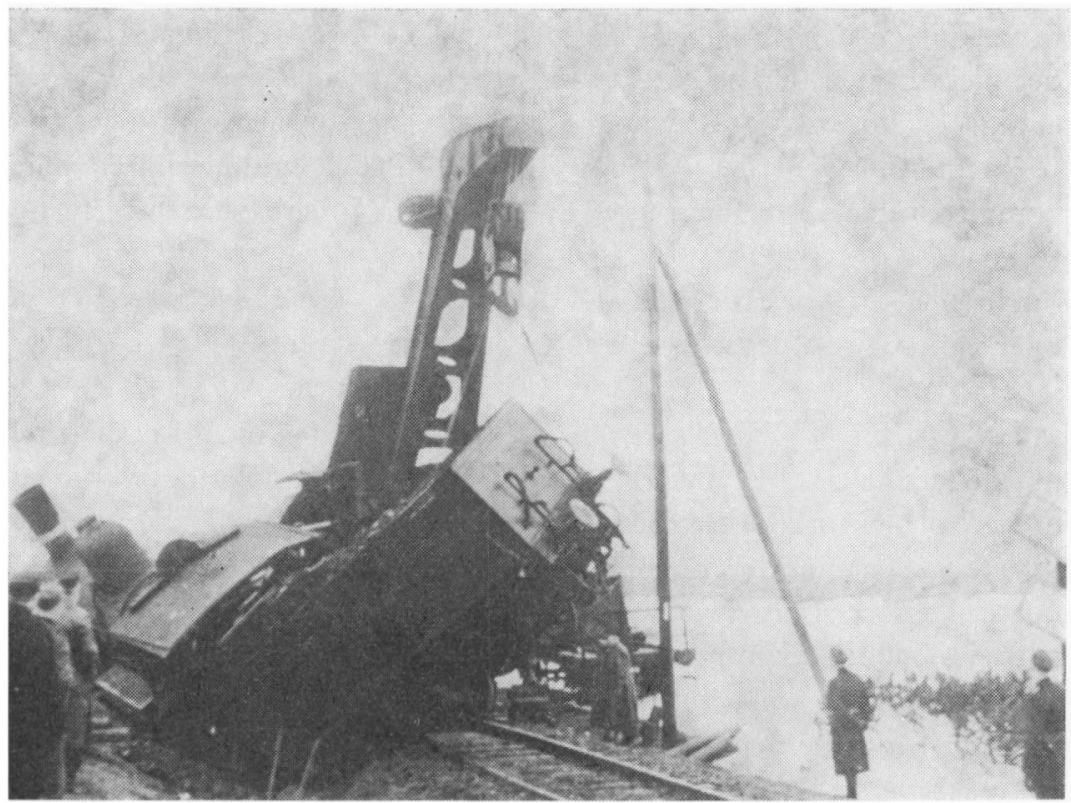

Sabotage 1945. Vaeltet tog på Lunderskov-Vamdrup-linjen. (DSB jernbanemuseet).

Ovre på østbanen blev det ligeledes en dramatisk nat. Her var planlagt en meget omfattende aktion: Hovedstødet skulle føres mod banen ved Søgård, d. v. s., der skulle her finde en afsporing sted, medens sporene nordpå ved Farris station blot skulle ødelægges ved almindelig sprængning, og det samme skulle finde sted læengere mod syd ved Fuglsang. Linjen var meget stærkt bevogtet.

Ved Søgård når man rigtignok frem til linjen; men midt under arbejdet indfinder vagten sig. »Halt! Wer da? « bliver der spurgt. Bombemanden, der befinder sig midt mellem skinnerne, springer ned på den modsatte side af jernbanedæmningen, og vagten lægger sig på den anden. De udveksler en del skud. Et af projektilerne rammer skinnen og slynges over mod én af vore folk, der bliver ramt over øjet. Blodet flyder rigeligt, men såret er ganske ufarligt. Det lykkes omsider bombemanden at få tågesignalerne anbragt på sporene. Skydningen har kaldt en del vagter til; men vore folk er på dette tidspunkt $\mathrm{i} l \mathfrak{x}$, idet de afventer, hvad der videre sker. Snart bliver de vidner til, at vagterne samler sig omkring afsporingsladningen. 
Hvad vil de dér? Vil de fjerne den? Én af vore folk fremkommer i det øjeblik med den replik, der blev bekendt $\mathrm{i}$ den hele region: $\gg$ Det er sku' da vores bomber «, hvorpå flere lægger sig ned og roligt fyrer på vagterne, der øjeblikkeligt er væk. I det samme høres toget komme, nærmere og nærmere. En befriende følelse vokser frem hos folkene.

$\mathrm{Nu}$ må det være der. Ja - detonationen giver genlyd langt ud over egnen: Et orlovstog er ramt. Fire store fire-akslede vogne forlader sporet.

Hver aktion havde sine sarlige oplevelser. Noget af det, der gjorde denne nat dramatisk, var det forhold, at lokomotivet medbragte projektører, der pludselig sendte deres lange lysbundter ud over hegn og marker. En helt ny fremgangsmåde. Men gruppen var borte. Den voldsomme detonation viste sig at have en uventet, men særdeles heldig virkning. Nordfra og sydfra kom de tyske vagter strømmende til; de forlod deres poster, og vor nordlige og sydlige gruppe var ikke sene til at udnytte denne gunstige lejlighed. De arrangerede deres sprængninger på begge sider af det afsporede tog og forsinkede derved hjælpearbejdet væsentligt. D.S.B. opgiver dog kun én sprængning klokken fire om morgenen.

Stemningen på hjemturen var præget af de dramatiske begivenheder og af det smukke resultat; men hjemturen var denne gang ikke fredelig og risikofri. Mange tyske patruljer kørte og gik ad vejene - endog ret langt fra banelinjen. Og da folkene endelig kom hjem - den ene altså ret oversmurt med blod $i$ ansigtet - fik de at vide, at de måtte tage sig $\mathrm{i}$ agt, da én mand var gået tabt ude på vestbanen. Natten igennem blev der holdt vagt ved villaen på Møgelmosevej. Men himlen være lovet blev det ikke Gestapo, men den savnede, der hen på morgenstunden meldte sig i Rødding. En meget begivenhedsrig nat var dermed gået til ende.

Vamdrup-Farris-strækningen optræder i statsbanernes sabotagerapport igen allerede den 28 . marts. Det hedder: Kl. 23,50 sprængning under dansk godstog. Otte vogne væltede. Syv vogne afsporede. Fem tyske soldater sårede«. Når det sidste meddeles, er der sket noget alvorligt. Vi har i nogle tilfælde kunnet konstatere, at der dræbtes og lemlæstedes flere, end statsbanerne opgav. Vi har kunnet støtte os til f. eks. antallet af leverede kister. 
På den tid var sabotageordrerne således, at de gav bestemte grupper bestemte dage at arbejde $i$, og til gengxld fik hver gruppe en meget stor strækning. Den 28. kunne Langetved således arbejde efter behag mellem Lunderskov og Padborg. Alligevel valgte de den kendte strækning omkring Farris-linjen, idet de gjorde et fremstød over Bastrup mose. Hvad er det, der huskes fra netop denne aften og fra netop denne ekspedition? Jo. Man kom i kontakt med tropper, som var dygtigere og mere trænede end dem, man sædvanligvis stødte på. - Selve fremrykningen forløb godt; der var ingen vagter af betydning på linjen, og netop som man kom op på banelegemet, nærmede der sig et tog med tropper og materiel. Der måtte handles hurtigt. Bombemandens karabin er borte i skyndingen, men man finder den igen. Alt forløb planmæssigt. Som sagt løb syv vogne af sporet, og otte vogne væltede fuldstændigt. Adskillige tyske soldater måtte nødvendigvis blive såret, og det er et under, hvis ingen blev dræbt. Det tyske militær var tydeligvis også meget utilfreds med dette arrangement. Utilfredsheden ytrede sig på en original måde, idet en luftværnskanon på en af de uskadte vogne begyndte at bjxffe ud i mørket. Man kan lykønske egnens befolkning til, at ingen gårde blev ramt; det kunne yderst let være sket. Soldaterne på toget akkompagnerede kanonen med deres karabiner, og for en gangs skyld oplevede man her at komme ud for soldater, der ikke skød for højt. Det var trænede folk. Heller ikke denne gang lykkedes det dog at ramme nogen.

I lang tid efter var det ikke ufarligt for egnens befolkning at komme i nærheden af det væltede tog. Tyskerne skød for et godt ord og var særdeles nervøse og ophidsede. Opholdet i Farris bekom dem åbenbart ikke godt, og de bandede højlydt over den fjendtligsindede befolkning.

Den 3. april var Langetved-gruppen under ledelse af gruppeføreren, gdr. Kresten Hanssen, ude på en ekspedition, der ikke blev uden følger. Gruppen meddelte skriftligt arbejderne på de tyske arbejdspladser ved Skodborg og Københoved, at inden den 5. april k1. 12 måtte de have forladt deres arbejdssteder, da de ellers selv måtte tage følgerne af, hvad der videre skete. Alle arbejderne forsvandt - og denne fremgangsmåde blev forbilledlig for alle lignende aktioner $\mathrm{i}$ Region III. Regionsledelsen gav nemlig straks ordre til at 
følge eksemplet fra Langetved, og efter kort tids forløb var der ikke flere danske arbejdere på tyske arbejdspladser i Sydjylland. Skade kun, at denne aktion ikke var blevet iværksat på et meget tidligere tidspunkt.

De $\mathrm{R}^{1}$-folk, der læser denne beretning, vil sikkert undre sig over, at der ikke var flere aktioner end de her nævnte. Nu bagefter har vi indtrykket af, at vi var ude særdeles ofte - og det er også nok sandsynligt, at denne redegørelse har glemt en del småudflugter, der ikke i særlig grad har bidt sig fast $i$ erindringen.

En sådan mindre udflugt blev foretaget den 7. april af en gruppe kombineret af Rødding- og Langetved-folk. Ekspeditionen havde netop udflugtens karakter. Vejret var mildt - og stemningen var hyggelig og munter. Vagter var der ingen af, og stedet var man godt kendt med: det var lige vest for Tirslund plantage, hvor vi i sin tid havde sat ind med de første aktioner mod tværbanen.

Efter at have lagt bomberne smukt til rette tog gruppen ganske simpelt hjem - vel tilpas - som var der ikke krig i landet. Bomberne sprang tidligt om morgenen og forårsagede 15 almindelige sprængninger.

Vi måtte egentlig prise os lykkelige, at vi aldrig var uheldige at vælte et dansk tog eller dræbe en dansk lokomotivmand. Ganske vist passede vi på. Vi var opmærksomme på dette forhold. Men engang var et forsinket dansk persontog netop kørt forbi os, - iøvrigt til vor ærgrelse, da det nærmede sig - men naturligvis til vor store glæde, da det havde passeret. Var vi kommet fem minutter før til stede, var der sket en ulykke.

På samme måde var Langetved-folkene glade for, at det lazarettog, de væltede den 11. april (eller afsporede?), var tomt. Der sad os trods alt endnu nogen respekt for folkeretten i blodet. Afsporingen skete ved gården Sjølund på østbanen.

Gruppeføreren løb lige ind $\mathrm{i}$ den tyske vagt, der standsede bag et hegn og dér ventede et kvarters tid. Længe lå han og var forberedt på alt. Imidlertid har tyskerne vistnok kun hvilt sig, for uden at være i nogen henseende påpasselige forlod de stedet og fortsatte deres monotone vandring langs linjen. Gruppen lagde denne aften en $11 / 2 \mathrm{~kg}$ bombe ud til afsporing og nedgravede desuden en del bom- 
ber for at forsinke reparationsarbejdet. Imidlertid væltede der ingen vogne; maskinen blev ganske vist af en eller anden grund utjenstdygtig, men skaden var ret hurtigt udbedret. Aktionen hørte ikke til de mest effektive i Langetved-gruppens glorværdige historie, men den fortjener $i$ hvert fald at blive nævnt.

I vinterens løb havde vi været opmærksomme på, at nogle tyske biler nu da blev brændt af i Rødding. Vi var meget irriterede over dette, fordi disse aktioner kun kunne tjene til at henlede Gestapos opmærksomhed på Rødding, og vi ønskede fortsat at ligge $\mathrm{i}$ fred inde $i$ landet. Imidlertid kunne vi ikke finde ud af, hvem der privat ødelagde disse biler; men vi satte en undersøgelse i gang, og en dag det var vist i Brørup - løb vi på en mand, der havde forbindelse med den uorganiserede Rødding-gruppe. Dermed fik vi hold på den. Denne gruppe var kun én gang fremme mod linjen; men denne ene gang gjorde den et særdeles virkningsfuldt stykke arbejde; gruppen havde medlemmer fra Rødding og fra $\mathrm{Hjerting,} \mathrm{og} \mathrm{aktionen} \mathrm{fandt}$ sted natten mellem den 14. og 15. april. I nærheden af gården Fuglsang rykkede fire mand frem. Et hegn forte $i$ retning af jernbanelinjen, og det fulgte man. Det sidste stykke vej måtte tilbagelægges over åben mark, men intet uheld indtraf. Vagterne var åbenbart ikke alt for mange. - Det var planen at lægge to afsporinger på linjen; men netop som bomberne var gjort færdige, og man løb op ad dxmningen, hørtes toget komme. Man fik travlt - og midt under arbejdet hørtes pludselig vagten komme. Man løber ned ad dxmningen. Toget nærmer sig stadig. En lykke var det, at vagterne fjernede sig $\mathrm{i}$ sidste øjeblik. Igen kommer man op på sporene, og fire $1 \mathrm{~kg}$ bomber bliver lagt på plads. - Toget kører ret hurtigt - i sidste øjeblik forlader folkene dæmningen og styrter ind på marken. Gruppen når at komme ca. 50 meter bort, inden to små knald forkynder, at tågesignalerne er slået an. Et oredøvende brag høres, vogne formelig valter mellem hinanden. Nogle af dem knuses ganske. Gruppen, der lige nåede at komme $\mathrm{i} d x k$ ning, da tågesignalerne var ramt, genoptager flugten. Få sekunder er der ganske stille; så hører de skrig fra sårede tyskere. De fortsætter, mens de obligate projektiler fløjter dem om ørerne. De når deres cykler og er samtidig uden for skudvidde. Det var for fjenden den dyreste af vore aktioner. Den kostede 10 døde og mange sårede. Afsporingen fandt sted 
den 15. april kl. 0,45. Som følge af denne aktion og brosprængningen den næste nat blev trafikken først genoptaget den 21 . april kl. 10,30.

Om sprængningen af broen over Nørre $\AA$ ved Sommersted få hundrede meter syd for det væltede tog - en aktion, forstander Demuth har omtalt $\mathrm{i}$ hørespillet "Fordi vi måtte« — skal berettes følgende:

Stemningen inden en aktion i det værelse, hvor man samles, er vist altid således, at alle bander usædvanlig meget og gør en masse vrøvl, uden at nogen tager spor notits af det. Man kan ikke bortforklare, at der er en skjult spænding til stede - nervøsitet om man vil. Det er godt at komme ud i morket og gå i gåsegang. Nogle er tavse, mens man går, andre stiller til stadighed dumme spørgsmål. En kilometer fra jernbanen mødes alle 12 mand på et aftalt sted, og så går vejen ind over markerne, frem mod broen. 12 mand har før følt sig trygge $i$ hinandens selskab. Den forreste har en bidetang med sig. Han klipper pigtrådshegn over. Uden støj eller snak går man gennem pløjejord, over diger og grøfter. 300 meter fra broen gør man holdt for at sætte detonatorer fast på det hvide cordtex - d. v.s. gøre bomberne helt færdige. Det er store bomber, den ene er på $25 \mathrm{~kg}$, den anden er på 15. De er indpakkede i sækkelærred. En mand bliver sendt af sted for at se, hvorledes det er med vagter på broen og på linjen. Han kommer ret hurtigt tilbage og melder, at der er to mand på selve broen og to patruljerende poster på banelegemet. En meget gunstig melding. Det er en dejlig nat. Næsten hele himlen er stjerneklar. Lunt er det, og vinden er god, den er østlig. Klokken er omkring midnat, måske er der vagtskifte nu. Det er klogt at vente, til det er overstået. Derfor hviler man sig. Der er en kilde, der klukker på en aldeles underholdende måde. Det er ikke den eneste lyd. Nogle hundrede meter langere mod nord hører vi, de arbejder på linjen. Det sker ved kraftigt projektørlys. Det er det tyske transporttog, som vor nye gruppe væltede aftenen før. Der blev altså dræbt ti tyske soldater. Det ved vi. Sporet er ikke ryddet endnu. - Ovre på dxmningen ser vi det fremskudte signal ved Sommersted station blinke regelmæssigt og roligt. På linjen tænder vagterne nu og da deres lygter. Det har vi set så tit. Vi ved ikke, hvad det betyder. Så bliver der klar til fremrykning. Fire mand skal dække broen fra nord og fire fra syd, to skal anbringe ladningerne, og to skal tage sig af vagterne $\mathrm{m}$. m. - Forsigtigt rykker man frem langs åbredden gennem 
det høje græs. Så tegner broen sig aldeles tydelig og sort op mod den østlige himmel. Også vagterne står deroppe med deres store regnslag og geværer. Få øjeblikke efter er de råbt an. Den ene løber, den anden reagerer ikke. Han opfordres endnu engang til at strække våben, men løber ind $\mathrm{i}$ det lille skilderhus ved broen. Vil han hente håndgranater, eller hvad vil han? To maskinpistoler knalder, og tolv mand løber op ad dxmningen. Fire mand mod nord, fire mod syd, to går $\mathrm{i}$ arbejde med bomberne, og to tager sig af den sårede vagt, trøster ham og hjælper ham på bedste måde. Tyskerne skyder fra nord, projektilerne fløjter langs skinnerne, men det er for alle en tilfredsstillelse, at enhver også denne gang bliver ved sit arbejde. Bombemændene lægger ugenerte deres ladninger, og mod nord besvares ilden roligt fra tre maskinpistoler og en karabin. Tyskerne skyder igen, og vore fire mand fyrer atter mod glimtene derude i morket. Så bliver der stille. "Klar« bliver der råbt, og fra syd trækker fire mand sig tilbage over broen. Den sårede bliver i sidste øjeblik slæbt ned ad dæmningen i læ. Nordpå trækker folkene sig igen tilbage. Der er tændt en $3 \frac{1}{2}$ meter bickford-lunte, d. v. s., broen sprænges om ca. tre minutter. For fuld fart løber alle hen mod et dige 200 meter længere fremme $-i l \mathfrak{l}$ af det afventer man detonationen. Den synes at udeblive. Bickford-lunten kan svigte, men for en sikkerheds skyld er der også anbragt to sikkerhedsblyanter på bomben. Skal de tænde, vil sprængningen imidlertid først finde sted om ca. ti minutter. Midt under forhandlingerne kommer det voldsomme glimt. Et pludseligt helvede af ild slår ud fra broen, og en yderst hul detonation ruller hen over egnen. Ekko svarer, og braget forsvinder ud mod horisonten og bliver borte fjernt bag skovene ved Gram. Da man i gåsegang forlader stedet og vender sig om, falder der en mild regn af gnister ned over det sted, hvor broen var.

I tiden efter brosprængningen var Rødding-grupperne travlt beskæftiget med at anbringe bomber på tyskernes arbejdspladser, at ødelægge biler, der kørte for tyskerne, og at slå heste ned, som stadig arbejdede for værnemagten. Unge landmænd var ikke glade ved at skyde heste. Den samme mand, der ramte den tyske soldat med en håndgranat uden at være generet deraf, kom særdeles dårlig tilpas tilbage efter at have dræbt to heste, der stod på stald. At ødelægge biler var derimod en sand svir, næsten hver nat bød på en eller anden udflugt, der oftest var ganske ufarlig - men dog virkningsfuld. 
Den 19. april generedes Rødding-gruppernes arbejde af, at den tidligere byleder blev arresteret. Han var netop kommet hjem fra en tur til grænsen for at tilrettelægge et kurérsystem til brug i påkommende tilfælde og havde lige haft et møde med Højland Christensen i Vejen. Han gik forbi højskolen for at begive sig til sin dxkbopæl i nærheden. På skolen brændte et lys, man havde glemt at slukke, og da han havde bragt dette $i$ orden, opdagede han, at der var fest på et af karlekamrene. Der gik han op. Midt under en festtale kom tyskerne ind og arresterede ham. Han blev sammen med de mandlige medlemmer af selskabet ført til kommandanturen i Rødding, nægtede og blev ført til Ribe. Undervejs mislykkedes et flugtforsøg. Derefter blev han ført til Kolding. Sad ti dage under forhør på Staldgården under de sædvanlige omstændigheder, begyndte at bekende Rødding-forhold søndag morgen, sad i Kolding arrest til kapitulationen, ventede på, om sagens afslutning eller om englænderne ville komme først.

Denne arrestation førte til, at Rødding-grupperne blev revet op. Dette forhindrede dog ikke, at grupperne havde kontakt med hinanden - en kontakt, der til sidst gjorde det muligt for dem at fortsætte arbejdet. Arrestationen havde for bydistriktets vedkommende til følge, at Lunding, Hans Poulsen og skrædder Dinesen, Jels, blev taget af Gestapo og ført til Kolding.

Gestapo var også ude efter føreren for Langetved-grupperne, Kresten Hanssen, kaldet Kedde. Kedde havde, som det allerede fremgår af det foregående, gjort et fremragende stykke arbejde på østbanen. Han var en stille, ung, ugift landmand, der havde en udviklet sans for boglige sysler, for historie og poesi. Han var følsom og nænsom af væsen, såre beskeden af fremtræden, men dog præget af den selvstændighed, man kan møde hos tænksomme landmænd, der tilbringer en hel del tid alene med sig selv. Ingen ville på forhånd formode, at Kedde havde anlæg for sabotage. Han var drevet af en indre følelse af pligt, ikke af nogen naturlig tilbøjelighed for krigshåndværket.

Også Keddes broder ${ }^{16}$ var med. På Keddes gård "Højvang “ boede endnu et par af Rødding-folkene, der havde måttet tage hjemmefra. I stedet for nu at forlade stedet gjorde man sig tværtimod klar til at modtage Gestapo. Man lagde sig om natten uden for gården $i$ en 
halmstak med MP'erne parate, og der ventede man - men Gestapo kom ikike.

Mandag aften var der filmforestilling i forsamlingshuset i Langetved. Kedde var ubetænksom og tog derned. Der vistes Hakon Mielche-filmen »Glimt fra Amerika«. Netop da lyset var blevet tændt, fordi der skulle skiftes spole, og man skulle gå over til en ny afdeling, siger fremviseren: "Den første afdeling har måske kedet Dem lidt, men nu skal De komme ud for noget spxndende «. I det samme går døren op, og en kone melder, at to mand spørger efter Kedde Højvang. Kedde anede uråd, men gik udenfor. To Gestapofolk tog imod ham, hver $\mathrm{i}$ en arm. Det lykkedes Kedde at få hånden ned $\mathrm{i}$ lommen og trxkke en håndgranat frem; han nåede at kaste den lige for indgangen. Politifolkene slap ham straks og begyndte at skyde. Han væltede om på gulvet, men kom hurtigt til kræfter igen og løb ind i salen, op gennem lokalet (forsamlingen var blevet borte under bordene) og op på scenen. Gestapo-folkene fulgte efter og skød, men ramte ikke. Fra scenen førte vinduer ud i det fri, og en vældig strøm var allerede på vej ud. Kedde ville ogsă ud ad et vindue, men en Gestapo-mand stod nedenfor. Han skyder ham med sin »Elefant«. Gestapo-manden ligger rolig udstrakt på jorden, og derefter løber Kedde til et andet vindue, kommer ud ad det og løber op over markerne ud i mørket. Han ved, at han er ramt, men endnu kan han løbe. Efterhånden mærker han, at kræfterne svækkes. Der er stærk skydning bag ham; men omsider når han frem til folk, der kun langsomt forstår, at han skal hjxlpes. Det skal dog siges, at da det først er gået op for folkene, hvad der er på færde, skorter det ikke på hjxlpsomhed, og snart kommer Kedde under kyndig behandling. Under et tag ligger han $\mathrm{i}$ et døgn. Det kniber med vejrtrækningen. Lungen er ramt. Men det går. En søndag formiddag bliver han kørt bort fra præstegården, og efter at man har undersøgt ham på Brørup sygehus, bliver han bragt yderligere $\mathrm{i}$ sikkerhed. Få uger efter kapitulationen var han helt rask.

Alt dette til trods var forbindelsen mellem bylederen og grupperne således $\mathrm{i}$ orden, at da kapitulationen endelig kom, var Rodding bydistrikt fuldstændig rede til at overtage de opgaver, der da blev dem tildelt.

En spændende tid var dermed lykkeligt afsluttet. 


\section{NOTER}

Johannes Rosendahl blev født 24/10 1912.

Han blev cand. polit. 1938 og blev kort efter ansat som lærer ved Rødding Højskole. Her var han til 1946.

Rosendahl blev lokal tillidsmand for »Ringen og snart efter *Ringen«s reprasentant i Region IIIs ledelse.

Han blev arresteret af tyskerne $i$ foråret 1945 og sad en tid $i$ fangecellen på Staldgården $\mathrm{i}$ Kolding. Her kan man stadig se det Nietzsche-citat, han indridsede $\mathrm{i}$ muren: $\gg$ Halte hoch deine höchste Hoffnung $\times$. Han kom under tortur og måtte regne med dødsdom. Sagen mod ham nåede ikke at blive afsluttet. Den 5. maj 1945 kom han på fri fod.

Om hans arbejde siden er der fortalt $\mathrm{i}$ indledningen.

Johannes Rosendahl dede 29/9 1969.

Han har skrevet en bog om Karen Blixen, 1957, genoptrykt i 1968. Han har desuden leveret skriftlige bidrag til en del boger.

1. Daværende kaptajn Aage Højland Christensen, reprasentant for $*$ Ringen* til foråret 1944. Derefter leder af Region III. Ded 1961 som generalmajor.

2. Lxge Karl Teilmann. Efter krigen lage i Ärhus. Død 1956.

3. Musiker Lausen, identisk med grosserer Christian Lausen, Gram, født 1905, død 1969.

4. Anders, identisk med chauffør Hans Andersen, Haderslev. Dræbt under den tyske aktion mod Vedsted Landbohjem.

5. Poulsen junior, identisk med daværende premierløjtnant B. B. Iversen. Leder af regionen, til Højland Christensen i 1944 overtog ledelsen.

6. Frode, identisk med daværende politibetjent S. M. Petersen, byleder i Haderslev. I dag major i Haderslev.

7. Thygesen var som nævnt Højland Christensens dæknavn som representant for »Ringen . Da han blev leder af Region III, blev hans dxknavn Peter Jensen.

8. Søbæk, identisk med daværende premierløjtnant O. Stephensen. Nu oberstløjtnant O. Stephensen, Holbæk.

9. Per, identisk med Per Jebsen. Født i Bergen. Bedsteforældrene udvandret fra Broagerland til Norge. Per havde en fantastisk skæbne under krigen. Flere forgaves forsøg på at komme til England. Kom i stedet til Danmark. Blev arresteret af tyskerne. På vej til koncentrationslejr sprang han i Sønderjylland af toget. Kom siden til England og blev uddannet som faldskærmsjæger. Blev efter eget ønske kastet ned i Danmark og deltog i modstandskampen her. I dag er han skibsreder i Oslo.

10. Gårdejer Niels Bagger. Dengang Rødding, nu bosat i København.

11. Kresten Hanssen (Kedde), født 1906. Dengang som nu gårdejer på „Højvang*, Skodborg J. Broder til nr. 15 og 16.

12. Andreas Lunding, Jels. Dad 1969.

13. Arkitekt Aage Jensen, født 1914. Nu arkitekt i Gram. Brugte dengang dæknavnet Knud Petersen.

14. Sven Hoffmann - dæknavn Hans - dengang bankassistent. I dag kontorchef i Handelsbanken, København.

15. Inge Margrethe Hanssen, søster til Kresten Hanssen (note 11) og til Jørgen Hanssen (note 16). Boede dengang i Rødding. Nu gift Szkobel og bosat i Hjørring. 
16. Jørgen Hanssen, broder til Kresten og Inge Margrethe Hanssen. Dengang landmand hos sin broder i Skodborg, i dag lærer på Ungdomsskolen Vesterdal pr. Kauslunde.

\section{Tilføjelse:}

Under trykningen har fru Aase Rosendahl gjort opmærksom på, at ordet »vagtposten* i linje 13 side 168, der forekom i originalmanuskriptet, formentlig bør lases *vandposten $\ll$.

\section{TEKNISKE NOTER}

R J: Militær ventegruppe.

$R^{1}$ o: Sabotagegruppe.

MP ग: Maskinpistol.

MG o: Maskingevær.

"Langelænderen* ग: Særmelding fra B.B.C. Udsendt første gang 7. 2. 1945. En særmelding om aktion gjaldt for 3 dage. Aktionsudløsningen gentages 10. 2. 1945. 6,35 o: Pistol, kaliber $6,35 \mathrm{~mm}$.

Bickford-lunte э: Forsinkelseslunte, brændetid c. $1 \mathrm{~cm} / \mathrm{sek}$. 